\title{
Lean Smart Maintenance-Value Adding, Flexible, and Intelligent Asset Management
}

\author{
Hubert Biedermann and Alfred Kinz \\ Lehrstuhl Wirtschafts- und Betriebswissenschaften, Montanuniversität Loeben, Leoben, Austria
}

Received November 6, 2018; accepted November 24, 2018; published online January 9, 2019

\begin{abstract}
Maintenance is a strategic factor and a key enabler for smart production. Therefore, it needs to be intelligent - smart - and cost efficient - lean. The Lean Smart Maintenance (LSM) management concept combines these two perspectives and enables a value adding, efficient, and intelligent asset management for production with digitalization aspects. This paper introduces LSM and explains its major components. LSM consists of efficiency drivers, e. g. maintenance processes and planning, outsourcing, and effectiveness factors, e.g. data and knowledge management, qualification and maintenance strategy. The implementation of the instruments in a four loop controlling cycle with vertical data integration is important. Furthermore, a LSM implementation model is introduced. A LSM assessment methodology as implementation step is briefly explained. A maturity model is used to identify and improve the current state of asset management. The four step LSM implementation model is described.
\end{abstract}

Keywords: Lean Smart Maintenance Concept, Efficiency drivers, Effectiveness factors, Controlling cycle, Implementation

Lean Smart Maintenance - wertschöpfendes, flexibles und intelligentes Anlagenmanagement

Zusammenfassung: Agile, sich der zunehmenden Komplexität und Umweltdynamik stellende produzierende Unternehmen sehen die Digitalisierung und Anpassung der Managementinstrumentarien als Chance. Zunehmend rückt dabei die Anlagenproduktivität bzw. das Asset Management in den Vordergrund. Lean Smart Maintenance eröffnet diesen Unternehmen die Möglichkeit, eine dynamische, lern- und wertschöpfungsorientierte Instandhaltung zu implementieren, die nachhaltige Wertsteigerungen für das be-

O. Univ. Prof. DI Dr. mont. H. Biedermann ( $\square)$

Lehrstuhl Wirtschafts- und Betriebswissenschaften,

Montanuniversität Loeben,

Franz Josef Straße 18,

8700 Leoben, Austria

hubert.biedermann@unileoben.ac.at treffende Unternehmen generiert. Die Ausrichtung auf ein einheitliches Zielsystem unter der Prämisse der Wertschöpfung verlangt nach einer Anpassung der Steuerungsprozesse, -instrumente und -strukturen. Auf diese wird ebenso hingewiesen wie auf einen in der betrieblichen Praxis bewährten Implementierungsansatz, basierend auf einem entwickelten Reifegradmodell.

Schlüsselwörter: Wertschöpfung, Lernende Instandhaltung, Effizienz, Effektivität, Controllingsystem, Implementierung

\section{Introduction}

Companies must perform in a highly flexible and agile manner in a dynamic environment. One of the key success factors in such an environment is a life cycle oriented and sustainable asset management. As maintenance is a main part of asset management, it needs to be focused. Maintenance management must change towards the requirements of Digitalization (Industry 4.0) to become an enabler of the smart factory. Therefore, new concepts need to be developed [1]. The Lean Smart Maintenance (LSM) approach combining lean philosophy and smart maintenance-meets these requirements [2]. This paper introduces the new LSM concept and a model for its implementation.

\section{Lean Smart Maintenance Concept}

The LSM approach is a sophisticated maintenance concept to improve efficiency and effectiveness of asset management. Fig. 1 shows the development of the maintenance philosophy and management concepts, from break down maintenance to an increasing value creation contribution and maturity towards Lean Smart Maintenance.

The smart part represents the effectiveness perspective of LSM. Smart Maintenance stands for an intelligent and learning maintenance management focusing on continuous improvement and dynamic strategy adaption. Clas- 
Fig. 1: Maintenance Management Concepts [3]

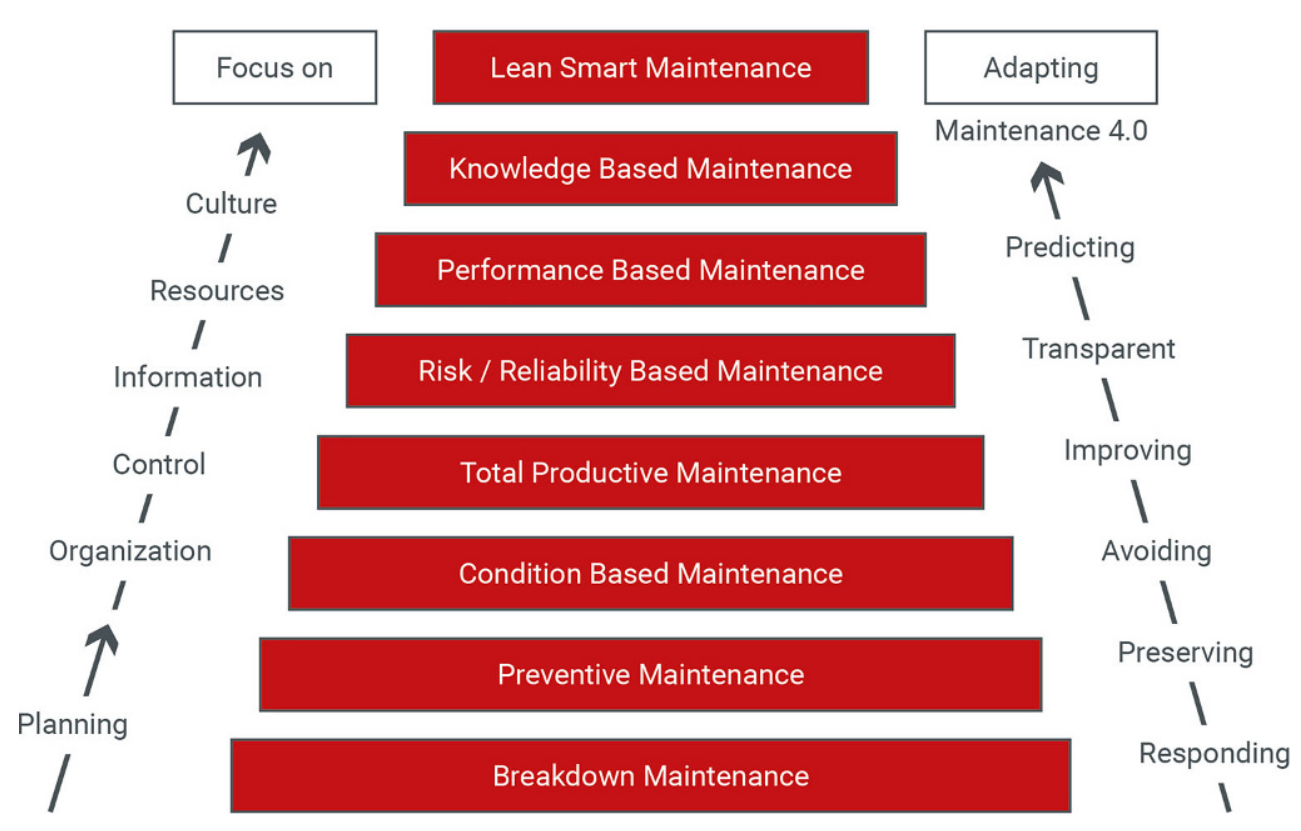

sic input control - cost oriented - is replaced by an output control, oriented on value creation contribution and reliability, availability, maintainability, and safety (RAMS). The lean part represents the efficiency perspective of LSM. The philosophy lies in the loss reduction on the input side of maintenance management system. Resource conservation underlines the sustainable orientation [2].

The dynamic strategy orientation focuses on failure avoidance through maintainability, predictive and perfective maintenance as well as weak point analysis (Fig. 2). The lean aspect focuses on improving the performance in personnel and spare parts management. LSM needs a comprehensive set of management tools, such as planning, organization, information, control, and personnel management for implementation (Fig. 2).

Below, the main management categories of LSM and requirements concerning LSM's high maturity level are introduced.

\subsection{Structural Organization}

The structural organization of the maintenance department specifies hierarchies, competences, responsibilities, and the degree of decentralization. In LSM the structural organization fulfils certain criteria, like: $[4,5]$

- Interdisciplinary teams (semi-autonomous working groups) are established and are responsible for operation and maintenance in a defined workshop area. The structural organization is dynamically adapted to changing conditions.

- The contribution of the teams to asset performance is measured and visualized.

- The span of control allows appropriate leadership and motivation.

\subsection{Process Organization}

Maintenance process organization comprises the planning and controlling of all maintenance activities. This includes, among others, the following criteria, according to LSM: [5]

- Comprehensive maintenance master data is available in an actual state.

- Dynamic capacity planning takes asset criticality into account.

- Initiation, implementation, monitoring, and feedback of each maintenance activity is done by the use of a standardized system and is improved continuously.

- Wrench-Time analyses to identify loss times [6].

- Non-productive and non-value adding times are recorded and reduced.

For example, by analyzing maintenance processes, nonvalue adding activities are identified. These are activities which do not contribute to a higher reliability or availability. Such activities should be reduced to a minimum.

\subsection{Target System}

The target system regulates maintenance goals according to content, dimensions, and time period. In LSM the target system: $[4,5]$

- comprises a written maintenance missions statement.

- is focused on value creation contribution.

- is derived from enterprise targets.

- is oriented on economic, ecologic, and human factors.

- is integrated in the maintenance control loop and is dynamically adapted. 


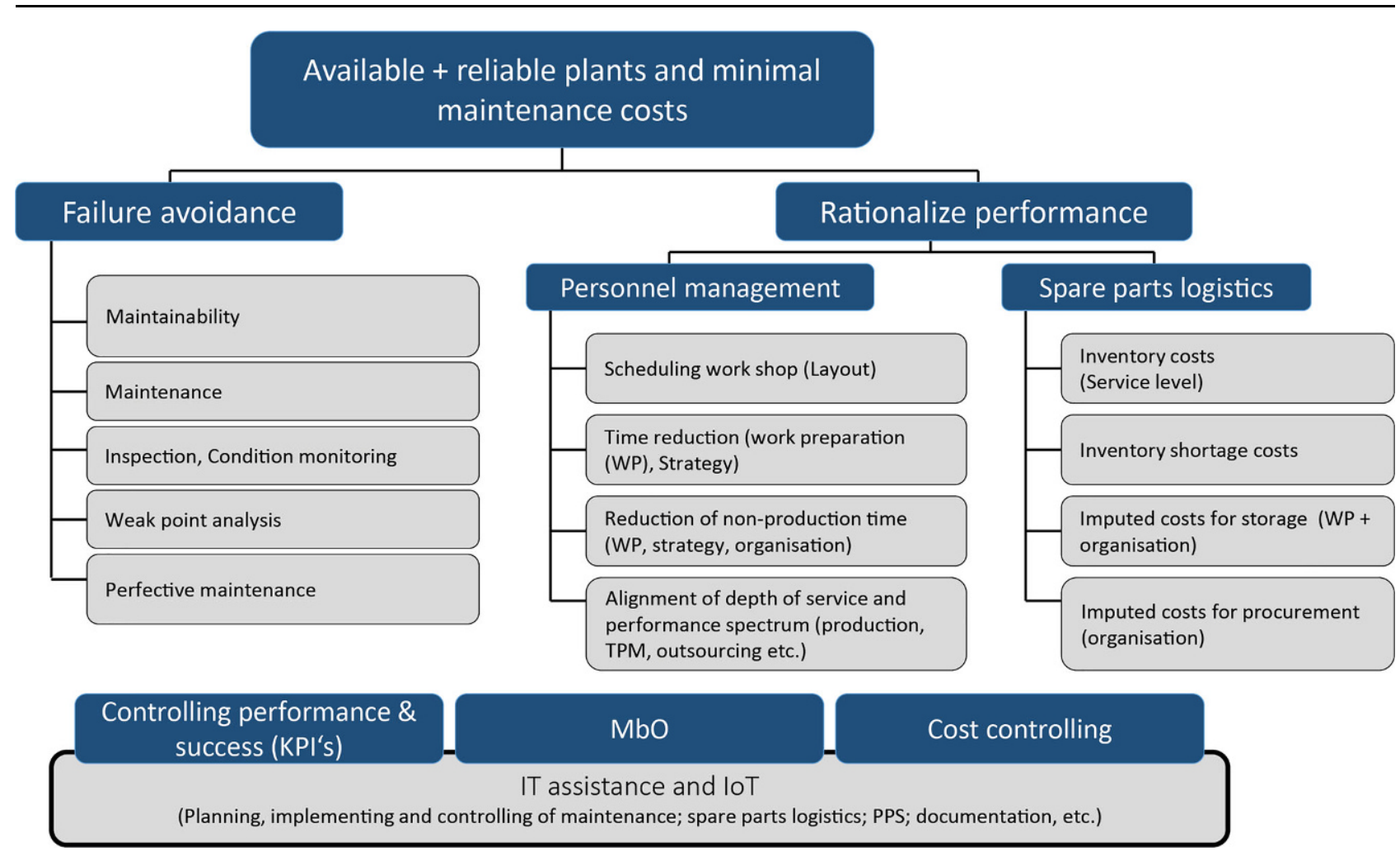

Fig. 2: Objective, dual strategy and instrumental framework of LSM

\subsection{Maintenance Strategy}

Maintenance strategy refers to general procedures and rules which determine object-related maintenance measures according to content, methodology, and scope in a specific chronological sequence. The criteria below characterize this management category in LSM: $[4,7]$

- All possible strategies - break down, preventive, condition based, predictive, and prescriptive-are mixed asset specifically in economic and risk oriented perspectives.

- Maintenance strategy mix is adapted dynamically to changing conditions.

- Assessment tools concerning of risk and cost criteria are used to classify dynamically all assets.

- Strategy selection process is integrated into the maintenance control loop.

\subsection{Maintenance Controlling}

Maintenance controlling has the task of coordinating and controlling maintenance measures as well as of providing information for problem-solving and decision-making processes. Key performance indicators (KPIs) are used to identify deviations between the target and the actual state. In LSM, maintenance controlling fulfils criteria like: $[4,8]$

- All necessary asset dependent sources of loss are recorded (OEE).
- Cause-effect relationships between enabler aspects as well as efficiency and effectiveness factors are transparent.

- Controlling loop is completely closed.

- Strategic success dimensions are integrated into the controlling system.

- Controlling system is continuously improved.

\subsection{Maintenance Budgeting and Internal Service Accounting}

Maintenance budget refers to the cost-oriented limitation of determined services for all maintenance objects. Internal service accounting is the causal allocation of maintenance costs to the respective service-related maintenance objects. The following criteria characterize this management category in LSM: [8]

- Budgeting process is future and risk-oriented.

- Asset specific cost allocation takes place on a detailed asset-structure level and is completely transparent.

- Budget overruns are analyzed and critically interrogated.

- Allocated maintenance costs are classified at least into planned and unplanned in-house, external, and material costs. 
Fig. 3: LSM Controlling System [15]

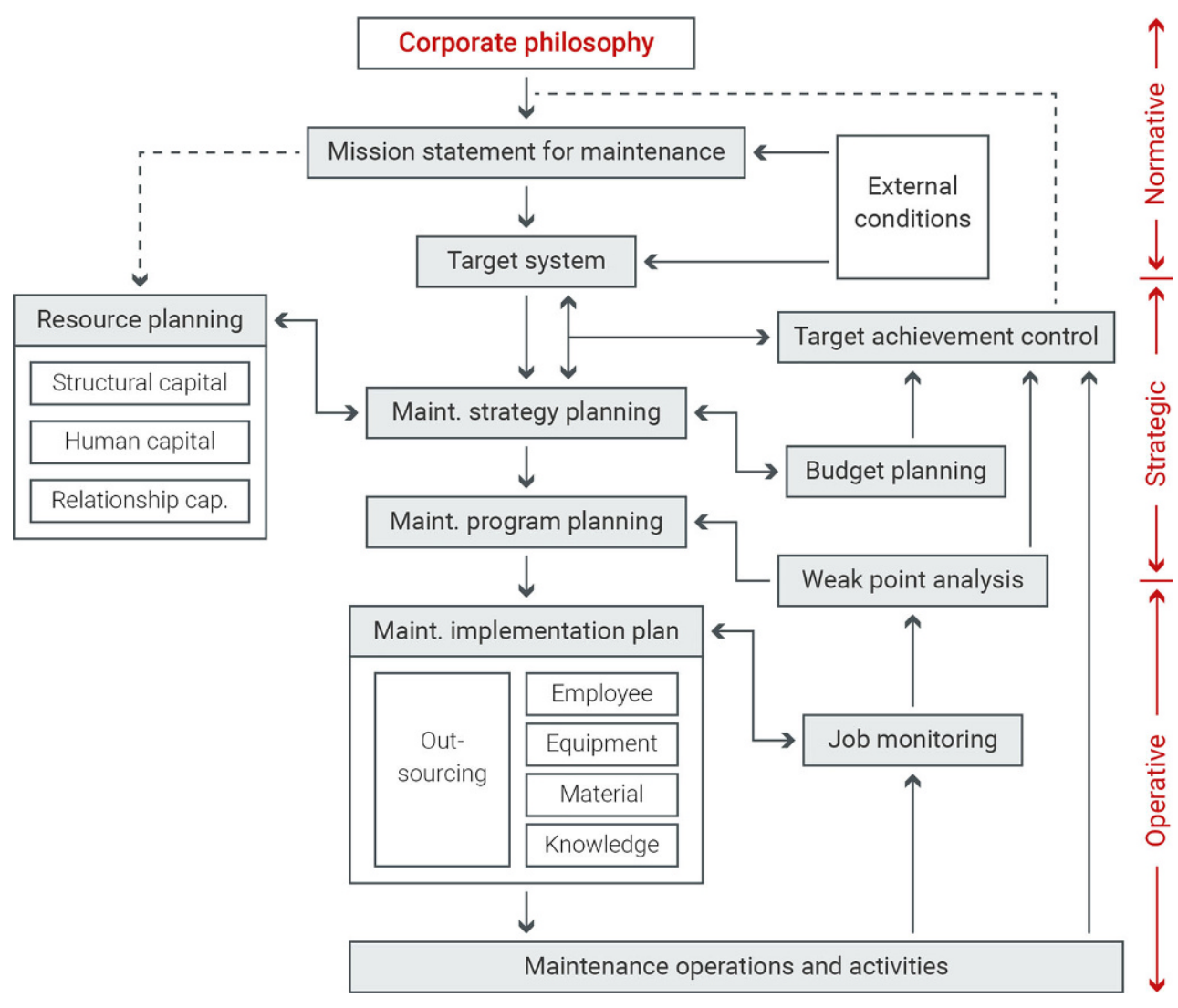

\subsection{Human Resources}

Concerning human resources, the shortage of skilled professionals and demographic change are challenges for maintenance. Especially in highly mature systems like LSM, several topics need to be focused on: [1,2]

- A knowledge management system is used to externalize and save the knowledge of experienced employees and to provide it to new ones.

- Balanced ratio between methodical, soft skill, and technical qualification activities according to current requirements.

- Intrinsic motivation is used to support the employees' potentials.

- Group premiums are used primarily. They are derived from the target system and are transparent as well as accepted by employees.

\subsection{Spare Parts Management}

The spare parts management in LSM is characterized by: [9]

- Spare parts management system is highly integrated with connections to all necessary functional areas (e.g. CMMS, purchasing, controlling, quality).
- A cost optimal service level is pursued for majority of spare parts.

For example, an assessment helps to identify critical spare parts. It builds the foundation of an efficient and lean spare parts management strategy. Models for breakdown predictions contribute to reduced storage costs.

\subsection{Continuous Improvement}

In an intelligent system like LSM, continuous improvement is obviously necessary in all relevant management categories. A special focus should be on: [5]

- A suggestion scheme for continuous improvement is installed. A majority of employees participate, and the premiums are transparent and accepted.

- Change is initiated top down as well as bottom up.

- Interdisciplinary teams are responsible for weak-point analysis and problem solving according to defined standards.

\subsection{Outsourcing}

The external strategically oriented procurement of maintenance services lies in outsourcing. The reasons for out- 
Fig. 4: LSM Implementation Model

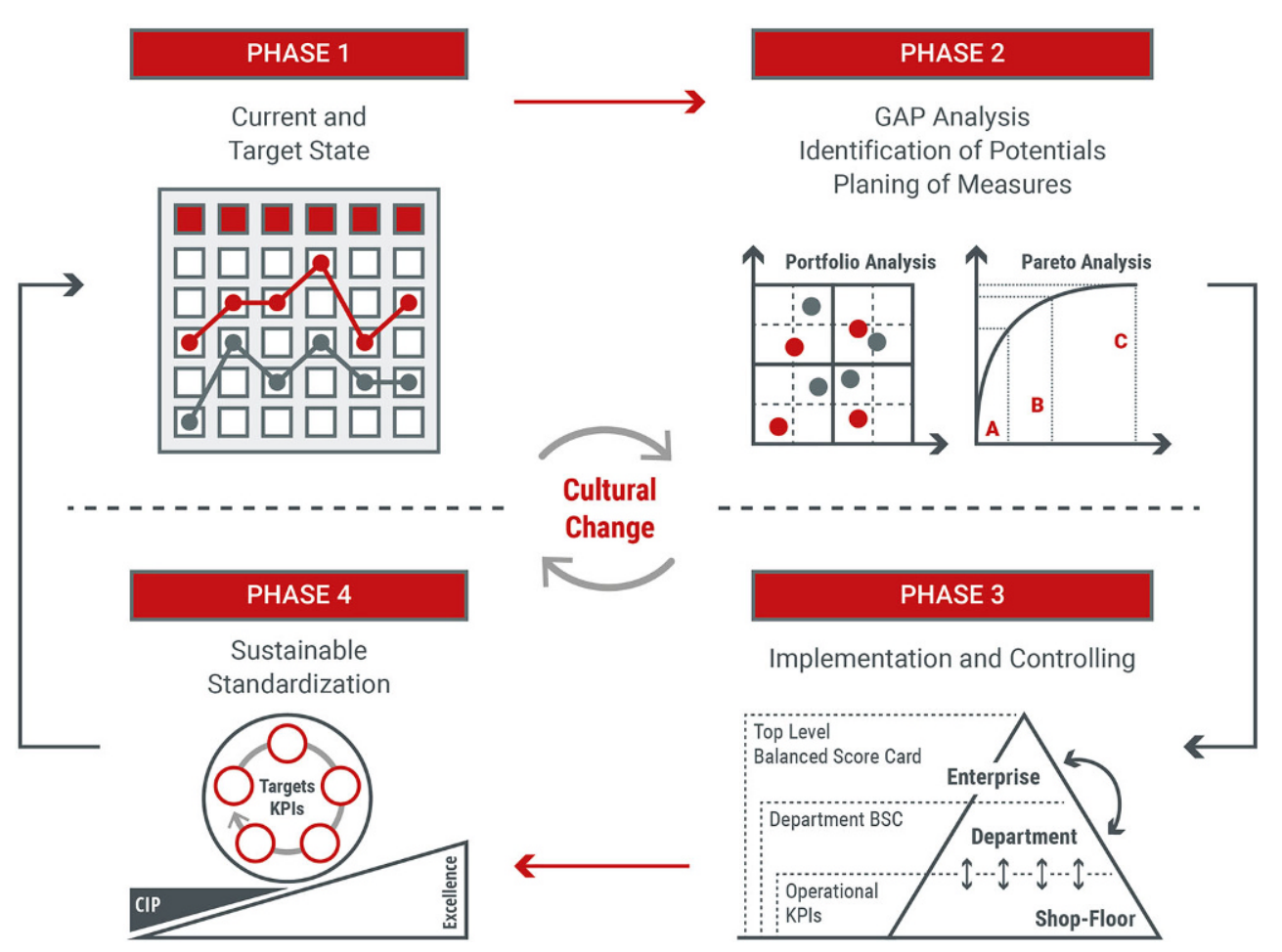

sourcing are linked to expected benefits, which are basically based on the strategic success factors: cost, quality, time, and flexibility. Outsourcing processes in LSM fulfill certain criteria, like: $[10,11]$

- Outsourcing is oriented to the company's own core competences

- Core competences are determined according to maintenance strategy

- Service relationships are long term oriented and regulated with service level agreements

- Transaction costs are recorded and optimized

- Supplier assessments are used to optimize service relationships

\subsection{Maintenance Prevention}

Maintenance prevention stands for early management of new equipment. Up to $80 \%$ of assets lifecycle costs are fixed in early stages of planning and construction. The knowhow of maintenance department needs to be considered in these early phases of investment to increase maintainability and to reduce failure and breakdowns. LSM criteria in this category are: $[5,12,13]$

- Defined standardized specifications for new assets and equipment.

- Standardized acquisition process for new assets involves maintenance department.

- Continuous improvement of standards and processes.

\subsection{Information Management}

Appropriate management of information and data is a very important success factor and key enabler for smart factories. Related to LSM, several factors are crucial: $[3,14,15]$

- Horizontal and vertical integration of computerized maintenance management system (CMMS).

- Economical application of technological resources (e.g. condition monitoring systems, mobile devices, visualization tools, and more)

- Necessary interface between technological resources, ERP-System, and CMMS is solved properly.

- Data is seen as a resource. For each data source, a producer, an owner, and a user are defined.

The appropriate controlling system must be implemented at the normative, strategic, and operational levels of management (Fig. 3). It consists of a controlling system with four loops and supports dynamic improvements, increases efficiency and effectiveness, and coordinates external and internal aspects by planning, organization, control and personnel management.

\section{Lean Smart Maintenance Implementation Model}

This chapter introduces a four step process model for LSM implementation, which is shown in Fig. 4. The model helps companies manage the change from a reactive maintenance management towards an efficient and intelligent asset management. Change management is a central success 
factor and needs to be focused on in each implementation phase.

Below, the four phases of LSM implementation model are described in detail. The management category maintenance strategy is used as an example.

- As a first step, a LSM assessment is used to identify the current state of maintenance management in all LSM management categories. For that the categories are integrated in a five stage maturity level model. ${ }^{1}$ Information for assessment is collected with a maintenance questionnaire, semantic analysis, benchmarking, and interviews on all hierarchical levels and in all relevant departments. The definition of the target state - maturity level in each category - is the final step in Phase 1. Depending on the current level, interim targets could be defined, which should be reached in the short-term - LSM maturity would be a long-term target in this case.

- Phase 2 of the LSM implementation model starts with a GAP analysis of Phase 1 results. By analysing definitions of the target maturity level and comparing those with the current state, potentials in each category can be identified. In interdisciplinary workshops these potentials are discussed and measures are derived. The result of Phase 2 is an action plan for all maintenance management categories.

- In Phase 3 the measures are implemented. Project management, progress check with suitable KPIs, and periodic controlling meetings are important instruments in this phase. Experience has shown that it makes sense to implement certain measures in pilot areas first and roll them out after the successful pilot implementation.

For a dynamic strategy adaptation, a periodic review of the asset prioritization portfolio needs to be done. An implementation into the maintenance controlling loop is recommended [4].

- Phase 4 , the sustainable standardization of achieved new status, is the final step of LSM implementation model. A lot of change projects fail because results and new processes are not integrated and standardized into daily business. Behaviour of management is very important in this phase - supported by, e.g.:

- Process descriptions of new procedures

- Internal trainings

- Communication and visualization

- Awareness building measures in middle and lower management

\section{Conclusion}

LSM combines the economic principles of an efficient input and output oriented asset management with a learning and

\footnotetext{
1 Forfurther explanations see [8].
}

knowledge based approach. It supports maintenance management to outline the contribution to a sustainable company's success. An efficient and effective asset management as a main objective can be achieved. LSM supports maintenance management in its evolution towards smart maintenance and enables the transformation to a smart factory.

Funding. Open access funding provided by Montanuniversität Leoben.

Open Access This article is distributed under the terms of the Creative Commons Attribution 4.0 International License (http://creativecommons. org/licenses/by/4.0/), which permits unrestricted use, distribution, and reproduction in any medium, provided you give appropriate credit to the original author(s) and the source, provide a link to the Creative Commons license, and indicate if changes were made.

\section{References}

1. Acatech - Deutsche Akademie der Technikwissenschaften: Smart Maintenance für Smart Factories: Mit intelligenter Instandhaltung die Industrie 4.0 vorantreiben, Berlin: Herbert Utz Verlag, 2016

2. Biedermann, H.: Lean Smart Maintenance, In: Industrial Engineering und Management, Springer Gabler: Wiesbaden, 2016, pp 119-142

3. Biedermann, H.: Lean Smart Maintenance: Wertschöpfende, lernorientierte und ressourceneffiziente Instandhaltung, in Biedermann, H. (Ed.): Lean Smart Maintenance, Köln: TÜV Media, 2016, pp 19-29

4. Biedermann, $\mathrm{H} .:$ Anlagenmanagement: Managementinstrumente zur Wertsteigerung, Köln: TÜV Media, 2008

5. Schroeder, W.: Ganzheitliches Instandhaltungsmanagement: Aufbau, Ausgestaltung und Bewertung, Wiesbaden: Springer Gabler, 2010

6. Uhlig, J.; Leitner A.-M.; Gläsel, U.; Winkelmann, S.; v. Gisteren, A.: Effizienzsteigerung in der Instandhaltung, in Biedermann, $\mathrm{H}$. (Ed.):Erfolg durch Lean Smart Maintenance, TÜV Media, Köln, 2017, pp 46-47

7. Kinz, A., Biedermann, H.: Anlagenspezifische Instandhaltungsstrategiewahl durch strukturierte Anlagenbewertung, in Biedermann, $\mathrm{H}$. (Ed.): Smart Maintenance, Köln: TÜV Media, 2015, pp 221-238

8. Kinz, A.: Ausgestaltung einer dynamischen, lern- und wertschöpfungsorientierten Instandhaltung, Diss., Leoben, Montanuniv., Lehrst. f. Wirtschafts- und Betriebswissenschaften, 2017

9. Biedermann, H.: Ersatzteilmanagement: effiziente Ersatzteillogistik für Industrieunternehmen, Berlin, Heidelberg: Springer, 2008

10. Kepplinger, W.: Erfolgreiches Outsourcing Instandhaltungstätigkeiten, in Biedermann, H. (Ed.): Risikominimierung im Anlagenmanagement, Köln: TÜV Media, 2003, pp 201-208

11. Feldmann, S.: Service 4.0 und Predictive Maintanance, in Biedermann, H. (Ed.): Erfolg durch Lean Smart Maintenance, Köln: TÜV Media, 2017, pp 235-245

12. Biedermann, H.: Smart Maintenance: Intelligente, lernorientierte Instandhaltung. In: Smart Maintenance, Köln: TÜV Media, 2015, pp 23-33.

13. Al-Radhi, M.; Heuer, J.: Total productive maintenance: Konzept Umsetzung, Erfahrung, München: Hanser, 1995

14. Kinz, A., Bernerstaetter, R.: Instandhaltungsoptimierung mittels Lean Smart Maintenance, in Biedermann, H. (Ed.): Lean Smart Maintenance, Köln: TÜV Media, 2016, pp 61-100

15. Biedermann, H.: Lean Smart Maintenance-Controlling, in Biedermann, H. (Ed.): Erfolg durch Lean Smart Maintenance, Köln: TÜV Media, 2017, pp 23-36 